\title{
"QUE ESTAS PÁGINAS SIMBOLIZEM UMA PASSEATA DE RAPAZES E MOÇAS": SOBRE CRÔNICAS CLARICEANAS PRODUZIDAS DO PERÍODO DA DITADURA MILITAR NO BRASIL
}

\author{
"I WISH THESE PAGES TO SYMBOLIZE A PROTEST OF BOYS AND \\ GIRLS": ABOUT CLARICEAN CHRONICLES PRODUCED FROM THE \\ PERIOD OF THE MILITARY DICTATORSHIP IN BRAZIL
}

Joyce Alves ${ }^{1}$

\begin{abstract}
RESUMO: Este artigo traz uma abordagem em torno de algumas crônicas publicadas por Clarice Lispector no Jornal do Brasil, entre 1967 e 1973, tendo em vista o fato de que foram produzidas no período da ditadura militar no Brasil. Os textos fazem parte da coletânea A descoberta do mundo, originalmente publicada em 1984, que reúne aproximadamente quatrocentas crônicas publicadas pela autora no período acima mencionado. Nesta mesma época, o cenário político do país foi marcado pelo regime militar e a cidade do Rio de Janeiro, onde a escritora morou até o ano de sua morte, em 1977, foi palco de significativas transformaçōes nas esferas políticas e culturais. A partir deste contexto, Clarice Lispector escreveu suas crônicas lançando mâo de uma apuradíssima percepçăo e evidente consternaçăo em face da situaçăo do país e, ao mesmo tempo, impulsionada pelo que chamo de parresía literária (ALVES, 2017). Aproveitando as palavras de Silviano Santiago (2014), o ativismo coletivo de Clarice Lispector "robustece a arte pelo avesso, liberando-a do compromisso que a literatura brasileira tradicional mantém com o acontecimento sócio histórico".
\end{abstract}

Palavras-chave: literatura; ditadura militar; Clarice Lispector; crônicas.

ABSTRACT: This article presents an approach based on some of the chronicles published by Clarice Lispector in Jornal do Brasil between 1967 and 1973, considering the fact that they were produced during the period of the military dictatorship in Brazil. The texts are part of the collection A descoberta do mundo, 1984, which contains approximately four hundred chronicles published by the author in the period mentioned above. At the same time, the country's political scene was marked by the military regime and the city of Rio de Janeiro, where the writer lived until the year of her death in 1977, was the scene of significant changes in the political and cultural spheres. From this context, Clarice Lispector wrote her chronicles, drawing on a very clear perception and evident consternation in the face of the situation of the country and, at the same time, driven by what I call literary parrhesia (ALVES, 2017). Taking

1 Doutora em Letras na área de Literatura Comparada pela Universidade Estadual de Londrina (UEL). E-mail: joycemiuki@hotmail.com 
advantage of the words of Silviano Santiago (2014), the collective activism of Clarice Lispector "strengthens art inside out, freeing it from the commitment that traditional Brazilian literature maintains with the socio-historical event."

Keywords: literature; military dictatorship; Clarice Lispector; chronicles.

\section{INTRODUÇÃO}

O cronista tende a recompor a própria história individual como uma maneira de também nos ensinar a compor a nossa história na condiçăo de pessoas ligadas a várias heranças culturais. Tudo isso por meio do registro do circunstancial. Por isso, de acordo com Jorge de Sá (1987, p. 15), é de fundamental importância que o cronista se defina num tempo e num espaço para compor uma cronologia esclarecedora da nossa relaçâo com os outros e com o meio. Clarice Lispector iniciou suas atividades no âmbito jornalístico praticamente ao mesmo tempo em que aprendeu a ler e a escrever. Segundo relatos da própria escritora, a fabulaçâo era algo natural que lhe vinha desde a infância. Por volta de 1931, Lispector soube de uma coluna infantil que saía semanalmente no Diário de Pernambuco e chegou a enviar alguns de seus primeiros textos, mas nunca foram aceitos (GOTLIB, 1995, p. 87).

Clarice Lispector começou efetivamente as atividades na redaçăo de um jornal por volta de 1940, no Rio de Janeiro, quando também era estudante da Faculdade de Direito. Na Agência Nacional iniciou uma atividade jornalística que se prolongaria por toda a sua vida, apesar de que com interrupçōes: "Trabalha primeiramente como tradutora. (...) Posteriormente, é transferida da Agência Nacional para o jornal A Noite e lá passa a trabalhar como repórter, tendo como colegas muitos dos que também trabalhavam na Agência Nacional" (GOTLIB, 1995, p. 150). Contudo, após a conclusăo do curso de Direito e de seu casamento com o diplomata Maury Gurgel Valente, em 1943, a escritora brasileira partiu para uma jornada de dezesseis anos fora do país para acompanhar os trabalhos do esposo. Nesse período, e depois da publicaçăo de seu livro de estreia Perto do coraçâo selvagem, em 1944, Lispector dedica-se à escritura de romances, além das muitas cartas enviadas às irmás e aos amigos.

No final da década de 1950, em seusúltimos anosnos Estados Unidos, Clarice Lispector colabora com colunas femininas para o Correio da manhâ, um tradicional jornal carioca dirigido na época por Paulo Bittencourt. Na coluna, intitulada Correio feminino - Feira de utilidades, Lispector assinava suas crônicas utilizando os pseudônimos Helen Palmer e Tereza Quadros. No Diário da Noite, mais especificamente para assinar a coluna “Só para mulheres", Clarice Lispector se apropria, ainda, do nome da atriz e modelo brasileira Ilka Soares, uma das mulheres mais bonitas da televisăo brasileira dos anos 50 e 60. Em 1960, Lispector passou a ser conhecida como o que os estudiosos de sua obra chamam de ghost writer de Ilka Soares. A impressâo é de que há nesses textos da escritora uma tentativa de atrair o público-alvo por meio de assuntos fúteis, o que nos traz um reflexo da mulher burguesa da época. As mulheres alfabetizadas e que tinham acesso a esse tipo de leitura pareciam estar pouco preocupadas com assuntos relacionados às desigualdades sociais ou à situaçáo política do país, por exemplo.

Após o divórcio em 1959, Clarice Lispector retorna definitivamente ao Brasil e instala-se no Rio de Janeiro. As dificuldades financeiras começaram a surgir, e a escritora 
passa a enviar textos a vários periódicos ao mesmo tempo. Apesar de acreditar que as várias atividades desempenhadas por Lispector na imprensa tenham resultado em objeto de análise do perfil literário da cronista, é no âmbito do Jornal do Brasil que a escritora trabalha efetivamente na produçăo semanal de crônicas. O primeiro grande diferencial desses textos é que a Clarice Lispector já năo se esconde por trás de pseudônimos. Diga-se de passagem, em pleno regime militar, Lispector assina os próprios textos de circulaçăo semanal pelo país e neles trata de variados temas, inclusive sobre a situaçăo política do país bem como as consequências sociais do regime ditatorial.

Assim, Benjamin Moser disserta sobre os aspectos culturais que conduziam escritores e leitores daquela época:

A crônica vivia seu apogeu: os cronistas eram figuras populares e até mesmo reverenciadas. Fosse porque, como escreveu Joăo Cabral de Melo Neto, "no Brasil, só entendem o que se escreve para os jornais", ou apenas porque os jornais ainda fossem o principal meio de comunicaçáo do país, o gênero era genuinamente popular. Seus praticantes incluíam muitos dos amigos de Clarice, entre eles Paulo Mendes Campos, Rubem Braga e Fernando Sabino (MOSER, 2009, p. 416).

Sobre o perfil escritural de Clarice Lispector, Rubem Braga, em crônica de 1965, para a Manchete, ao comentar os contos da escritora em Laços de família (1960), ressalta que "por mais introspectiva que seja a escritora, ela năo é alerta apenas aos tumultos e confusôes da alma, mas também, com uma sensibilidade especial, às luzes, aos rumores, às brisas e à temperatura, a detalhes da paisagem e do ambiente" (BRAGA, 2017, p. 53). De fato, essa "sensibilidade especial" se aperfeiçoará nas crônicas, sobretudo quando Lispector inicia os trabalhos semanais junto ao Jornal do Brasil em 1967. Os "detalhes da paisagem e do ambiente" somam-se à representaçăo de empregadas domésticas, meninos famintos pelas ruas do Rio de Janeiro, a pobreza, entre outros temas relacionados à miséria urbana. E, em meio a tudo isso, surge também o caráter reivindicador da cronista no que se refere ao período do regime militar. Em meio às aproximadamente quatrocentas crônicas reunidas em A descoberta do mundo (1981), Lispector traz resquícios de outras "ditaduras" presentes na história da populaçăo carioca.

\section{A DITADURA MILITAR E OUTRAS DITADURAS}

Em 1904, durante o governo do presidente Rodrigues Alves, a cidade do Rio de Janeiro foi palco de grandes rebelióes populares. $O$ entăo presidente tinha um programa de governo baseado na modernizaçăo do porto e na remodelagem da cidade. Deste modo, novamente muitas casas antigas foram demolidas para cumprimento dos processos de urbanizaçăo, e as famílias mais pobres foram retiradas da área central da cidade. A capital sofria, ainda, com problemas sanitários que culminaram na propagaçăo de doenças como a peste bubônica, a febre amarela e a varíola. Assim, a populaçăo que foi despejada estava ainda mais suscetível às doenças.

Alfredo Bosi lembra também as grandes levas de imigrantes europeus que se achegavam à capital e ali se instalavam, enquanto a populaçâo carioca mais pobre era enxotada para a periferia: "Paralelamente, deslocam-se ou marginalizam-se os antigos escravos em castas áreas do país. Engrossam-se, em consequência, as fileiras da 
pequena classe média, da classe operária e do subproletariado" (BOSI, 1997, p. 342). A populaçăo também crescia demasiadamente graças ao fluxo de migrantes advindos de outras regiōes do país, principalmente do Nordeste.

Para o presidente Rodrigues Alves, era primordial que o governo executasse um projeto urbano e sanitário a qualquer custo:

\begin{abstract}
Rodrigues Alves nomeia, entăo, dois assistentes com poderes quase ditatoriais: o engenheiro Pereira Passos, como prefeito, e o médico sanitarista Oswaldo Cruz, como chefe da Diretoria de Saúde Pública. Cruz assume o cargo em março de 1903: "Deem-me liberdade de açáo e eu exterminarei a febre amarela dentro de três anos". O sanitarista cumpriu o prometido. Em nove meses, a reforma urbana derruba cerca de 600 edifícios e casas, para abrir a Avenida Central (hoje, Rio Branco). A açăo, conhecida como "bota-abaixo", obriga parte da populaçăo mais pobre a se mudar para os morros e periferia (VIEIRA, 1994, p. 68).
\end{abstract}

Ocorre que o plano de Oswaldo Cruz para vacinar a populaçăo deu certo, mas o método de combate às doenças invadindo os lares, interditando, despejando e internando à força, năo foi bem-sucedido. $\mathrm{O}$ movimento que envolveu uma maioria pobre e negra forçou famílias a se abrigarem nos morros onde hoje se localizam as favelas. Famílias pobres inteiras perdiam espaço em meio aos projetos de urbanizaçâo e modernizaçăo da cidade. O Brasil agrário tornava-se urbano e, até que a capital Brasília fosse fundada em 1960, a cidade do Rio de Janeiro ainda sofreria consideráveis mudanças oriundas de períodos tấo revoltosos.

Entretanto, Daniel Reis (2014, p. 167) constata que a paisagem social acabou se transformando também por meio do ingresso das mulheres no mercado de trabalho e pelo protagonismo cada vez maior das populaçôes negras e pardas. Ora, mesmo passando por um processo de movimentaçăo do centro para a periferia, o destaque dado por Reis ao protagonismo de populaçóes negras, por exemplo, parece paradoxal. Mas trata-se, na verdade, de algo que pode estar muito claro, pois, mesmo diante de realidade miserável e frustrante, o trabalhador pobre brasileiro tenta, desde aqueles tempos, combater a resignaçăo.

Passados os anos, mais especificamente entre 1920 e meados de 1930, com o chamado tenentismo, houve revoltas militares que tiveram como cenário o Forte de Copacabana. No dia 5 de julho de 1922, ocorreu o que foi conhecido pela imprensa da época como revolta dos "18 do Forte". Segundo Carlos Fico (2016, p. 11), "dezenas de oficiais estavam no Forte de Copacabana, no Rio de Janeiro. Juntamente com os soldados, somavam cerca de trezentos militares. Tiros de canhăo foram ouvidos: era o início da revolta". No início do século XX, a cidade do Rio de Janeiro vivia dias sombrios.

Em meio a campanhas eleitorais, sequestros de autoridades e assassinatos, veio à tona a Revoluçăo de 1930 dando poder a Getúlio Vargas, que governaria o país durante quinze anos: "A Era Vargas foi marcada por grande violência, inclusive com conflitos militares: apesar do mito de que a história do Brasil é incruenta (...), Vargas chegou ao poder depois de confrontos sangrentos" (FICO, 2016, p. 9). Conhecido como "Pai dos Pobres", Getúlio Vargas beneficiou a classe dos trabalhadores, aprovando e decretando uma série de leis em favor deles. No 
entanto, o grupo dos favelados continuava à sombra da miserabilidade e à mercê da violência.

Além disso, a problemática em torno da fome infantil viria à tona alguns anos mais tarde como consequência desta situaçăo social. No livro Geografía da fome (1969), resultado de levantamento feito por Josué de Castro, exatamente entre 1940 e 1945, o autor apresenta o mapa da fome no Brasil. Castro, já na introduçâo do livro, explica que desde aquela época pensava-se na fome e na pobreza como algo distante da realidade local. Ninguém "via" a fome do outro, e imediatamente associava-se a falta de comida aos países do Extremo Oriente ou, naquele tempo, aos campos de concentraçâo nazistas. Porém, nenhum continente escapa à açăo das crises pela falta de alimento: "Mesmo o nosso continente, chamado do tal da abundância e simbolizado até hoje nas lendas do Eldorado, sofre intensamente o flagelo da fome" (CASTRO, 1969, p. 36).

Do mesmo modo, nenhuma regiâo do Brasil escapa aos problemas relacionados à fome. Por isso, o autor também desconstrói a ideia de que a fome no Brasil é uma realidade que atingia unicamente as regiōes Norte e Nordeste, ou as cidades interioranas e vilarejos. Para Castro (1969, p. 38), as causas fundamentais do que ele chama de "alimentaçâo defeituosa" sâo produtos principalmente de fatores socioculturais, e bem menos associados a fatores de natureza geográfica. Assim, todas as regióes do país sofriam naquela época com alguma das categorias de fome apresentadas pelo autor.

No caso da regiăo Sudeste, na qual se insere o estado do Rio de Janeiro, Castro considera ser a regiăo onde a fome se manifestava de forma mais "discreta ou oculta". Entretanto, marcada pela subnutriçăo, a regiăo também apresentava carências graves:

Uma delas se manifesta, no entanto, de forma gritante: é a carência de proteínas entre as crianças pobres dos grandes centros urbanos da regiăo. Em cidades como a do Rio de Janeiro e Sáo Paulo os pediatras têm constatado nos últimos anos uma incidência extremamente alta dos edemas de fome, das distrofias malignas e mesmo dos síndromes (sic) típicos de "kwaskiokor" entre as crianças atendidas nos hospitais públicos, nos bairros operários e nos subúrbios (CASTRO, 1969, p. 260-1).

O forte crescimento do capitalismo desencadeava as desigualdades sociais que, por sua vez, condenavam a populaçấo desfavorecida à miséria e à falta de alimentos. Este será um dos maiores incômodos de Clarice Lispector, desde os contos de Laços de família, de 1960, até a construçâo da personagem Macabéa em A hora da estrela, de 1977. Mas, sobretudo nas crônicas, a escritora fará insistentes críticas em relaçâo ao problema da fome: "Como suportaria eu a manchete que saiu um dia no jornal dizendo que cem crianças morrem no Brasil diariamente de fome? A raiva é a minha revolta mais profunda de ser gente? Ser gente me cansa" (LISPECTOR, 1999, p. 135).

Nota-se assim que, já nas primeiras décadas do século XX, mais especificamente no período desta ditadura quase apagada, as consequências mais terríveis atingiram a populaçâo que nâo deu conta de acompanhar, principalmente, o projeto cultural moderno. A censura moralizante impedia a parte burguesa da populaçâo - aquela que tinha mais acesso às informaçôes - de enxergar os problemas sociais. Assim, é preciso 
entender que a censura náo diz respeito apenas às ameaças diretas ao governo que eram impedidas de serem publicadas, mas também representa a tentativa de camuflar a realidade pelos meios de comunicaçâo:

\begin{abstract}
Desde os anos 1940, existia a censura de diversóes públicas, que cuidava de coibir "atentados à moral e aos bons costumes" no teatro, na música, no cinema e, após os anos 1950, na TV. [...] A censura moral se consolidou durante o Estado Novo de Vargas, mas cresceu muito durante a ditadura militar por causa do grande sucesso da telenovela brasileira. [...] Essa censura das diversōes públicas visava especialmente às questôes morais: exibiçăo de nudez, uso de palavrôes, abordagem de temas chocantes e assim por diante. Durante a ditadura militar, entretanto, ela foi "politizada", pois os censores da DCDP (Divisăo de Censura e Diversóes Públicas) foram obrigados a ficar atentos também às críticas ao regime em filmes, peças e músicas. [...] A censura propriamente política atingia, sobretudo, a imprensa. [...] Livros também foram censurados, sobretudo a partir de 1970, mas isso era praticamente inviável diante da enormidade da tarefa (FICO, 2016, p. 82-3).
\end{abstract}

Embora houvesse todo um empenho em impedir qualquer manifestaçăo contrária ao modo de organizaçăo social, política e econômica, além da literatura, outros meios de manifestaçâo artística foram utilizados para trazer à tona os problemas sociais causados pelo sistema opressor. É o caso da peça teatral Eles nâo usam black-tie, de Gianfrancesco Guarnieri, escrita e encenada em 1958 para o Teatro de Arena de Sâo Paulo. As entrelinhas do texto artístico tornavam-se um espaço de reivindicaçáo e denúncia. Na época, o sentimento nacionalista fazia com que os dramaturgos reforçassem o abrasileiramento nos palcos, e Guarnieri segue essa linha objetiva escolhendo a favela como espaço para a peça. Marcado pelo tema das greves promovidas pela classe operária, o texto reforça o caráter reivindicador dos trabalhadores insatisfeitos com os baixos salários.

Ainda em Sâo Paulo, durante os anos de 1960, os Festivais da Cançấo faziam bastante sucesso e eram promovidos por emissoras de TV como a Rede Record e a Rede Globo. Segundo Fico (2016, p. 79), as vaias eram frequentes e partiam de espectadores alvoroçados, como aconteceu com Caetano Veloso em setembro de 1968. Na ocasiâo, a letra da música, assim como outras composiçóes, tentava driblar a censura para criticar o regime militar, sendo classificada como "cançấo de protesto": "Eu digo nâo ao nâo. Eu digo. É proibido proibir. Me dê um beijo meu amor. Eles estăo nos esperando. Os automóveis ardem em chamas. Derrubar as prateleiras, as estátuas, as estantes, as vidraças, louças e livros, sim" (VELOSO apud FICO, 2016, p. 79). Na letra há o reflexo de que, de fato, muitos livros e discografias foram "derrubados" pela repressāo na época e nos anos subsequentes.

\title{
RIO DE JANEIRO E AS CRÔNICAS DE CLARICE LISPECTOR
}

O Rio de Janeiro já náo era mais a capital do Brasil quando foi instalado o Regime Militar no país após o golpe de 1964, mas a cidade sofreria por muito tempo com conflitos populares. Conforme Daniel Reis (2014, p. 77), desdobrava-se na cidade guerrilhas com ataques surpresas a quartéis ou a postos policiais, além dos sequestros de diplomatas estrangeiros. A sociedade assistiu a todo esse processo como se fosse uma plateia de 
jogo de futebol ou como espectadores de uma telenovela. O povo pouco compreendia o que se passava e acabava por reproduzir o que viam e ouviam sem questionar: "A isso se chama hegemonia, quando os vencedores conseguem fazer com que os vencidos usem o seu vocabulário, carregado de conotaçôes pejorativas" (REIS, 2014, p. 75).

Ocorre que, nesse período, mais especificamente em julho de 1968, foi criada a Aerp - Assessoria Especial de Relaçôes Públicas, cuja funçăo era analisar os conteúdos da imprensa em geral e determinar o que poderia ser tornado público ou năo. Além de defender a moral e os bons costumes, no entanto, o grupo de assessores também deveria barrar qualquer manifestaçăo contrária ao regime militar. Naquela época, o prazer fundamental das massas era a televisăo, e a própria populaçấo passou a deixar de lado os jornais impressos, passando a priorizar os telejornais, principalmente aqueles apresentados pela Rede Globo. Segundo Carlos Fico (2016, p. 85), a emissora apoiava o regime militar e seus telejornais expressavam o ponto de vista oficial dos governos militares. Porém, as novelas e os programas de entretenimento da Globo foram prejudicados pela censura moral, já que muitas cenas contendo adultério, mentiras, consumo de álcool, sexo livre e casais homossexuais eram cortadas por serem consideradas "maliciosas".

Por meio das emissoras de televisăo, essa "teia" conseguiu estabelecer uma notável interlocuçăo com a sociedade, confortando, entretendo, divertindo, integrando, embalando, anestesiando, estimulando, modernizando (REIS, 2014, p. 91). Contudo, a Aerp teve papel fundamental no controle aos programas que contribuíam para o agravamento da ignorância das pessoas. Nas palavras de Carlos Fico (2016, p. 80), a Aerp era uma expressâo "pedagógica", pois os brasileiros eram despreparados e precisavam receber noçôes básicas até mesmo de higiene e de civilidade urbana. A populaçăo carecia de instruçâoo em todos os sentidos.

Na crônica intitulada "Chacrinha", datada de 07 de outubro de 1967 e publicada no Jornal do Brasil, Clarice Lispector faz crítica ferrenha ao programa de televisâo apresentado pelo locutor que dá nome ao texto e destaca a desorientaçáo do povo que compunha a plateia e o grupo de calouros:

De tanto falarem em Chacrinha, liguei a televisăo para seu programa que me pareceu durar mais que uma hora. E fiquei pasma. Dizem-me que esse programa é atualmente o mais popular. Mas como? $\mathrm{O}$ homem tem qualquer coisa de doido, e estou usando a palavra doido no seu verdadeiro sentido. 0 auditório também cheio. É um programa de calouros, pelo menos o que eu vi. Ocupa a chamada hora nobre da televisăo. $\mathrm{O}$ homem se veste com roupas loucas, o calouro apresenta o seu número e, se năo agrada, a buzina do Chacrinha funciona, despedindo-o. Além do mais, Chacrinha tem algo de sádico: sente-se o prazer que tem em usar a buzina. E suas gracinhas se repetem a todo o instante - falta-lhe imaginaçăo ou ele é obcecado. E os calouros? Como é deprimente. Săo de todas as idades. E em todas as idades vê-se a ânsia de aparecer, de se mostrar, de se tornar famoso, mesmo à custa do ridículo ou da humilhaçăo. Vêm velhos até de setenta anos. Com exceçôes, os calouros, que săo de origem humilde, têm ar de subnutridos. E o auditório aplaude. Há prêmios em dinheiro para os que acertarem através de cartas o número de buzinadas que Chacrinha dará; pelo menos foi assim no programa que vi. Será pela possibilidade da sorte de ganhar dinheiro, como em loteria, que o programa tem tal popularidade? Ou será por pobreza de espírito de nosso povo? Ou será que os telespectadores têm em si 
um pouco de sadismo que se compraz no sadismo de Chacrinha? Náo entendo. Nossa televisăo, com exceçôes, é pobre, além de superlotada de anúncios. Mas Chacrinha foi demais. Simplesmente náo entendi o fenômeno. E fiquei triste, decepcionada: eu quereria um povo mais exigente (LISPECTOR, 1999, p. 36-7).

Nota-se que, além de destacar a questăo da subnutriçăo, a decepçăo maior da cronista reside na pobreza cultural do programa que resulta na paupérrima mentalidade distribuída em horário nobre. Pela ignorância, o povo brasileiro de um modo geral aceitava qualquer imposiçăo hegemônica difundida por meio da cultura de massa. A mortificaçáo coletiva do senso crítico da populaçáo começou pela fome do páo e pela miséria intelectual. O que subjazia o povo era exatamente a subalternizaçăo de conhecimento e a exaltaçăo de culturas medíocres que eram indigentes e indigestas. Naturalmente, em Clarice Lispector, há um componente que a torna uma cronista que reflete sobre as questôes sociais e traz essas reflexóes para a crônica.

Vale lembrar que, ao mesmo tempo em que barrou qualquer manifestaçáo contrária ao regime militar, a Aerp promoveu propagandas de valorizaçâo da cultura nacional e dos programas do governo voltados à saúde e à educaçăo no país. Alguns bordôes foram amplamente propagados a fim de encorajar a populaçăo com mensagens positivas e ufanistas, tais como: "Pra frente, Brasil"; "Ninguém segura este país"; "O futuro chegou”; "Brasil, terra de oportunidades"; "Brasil, potência emergente." E, para os que ainda discordavam, restava a porta de saída, conforme provocava outro bordăo de inspiraçáo norte-americana: "Brasil, ame-o ou deixe-o" (REIS, 2014, p. 81).

Porém, as tentativas de transparecer uma realidade organizada e com resultados otimistas acabavam caindo por terra, pois estavam cada vez mais evidentes as desigualdades sociais e, consequentemente, a insatisfaçăo da populaçăo. O grupo já enriquecido tornou-se mais rico, enquanto os setores miseráveis de base tornaram-se ainda mais miseráveis. Além disso, enquanto os pés de grande parte da populaçâo carioca afundavam em casebres insalubres, o olhar e a mentalidade das pessoas estavam nos Estados Unidos que, naquela época, inspiravam a sociedade brasileira como um modelo de país capitalista. Deste modo, corpo e cabeça pareciam estar muito distantes e dificilmente o vínculo com a própria terra, com os próprios problemas sociais, com a própria gente, estaria na pauta do dia a dia da populaçâo carioca. Daí a importância dos escritores, sobretudo os cronistas, que buscavam elevar o miúdo do cotidiano a fim de fazer vir à tona o que havia sido jogado para debaixo do tapete ou, melhor dizendo, despejado para os morros e periferias. Assim, seria possível ao escritor tornar-se "homem do seu tempo", lembrando a proposta de Machado de Assis, no artigo "Notícia da atual literatura brasileira. Instinto de nacionalidade", de 1873: "O que se deve exigir do escritor antes de tudo, é certo sentimento íntimo, que o torne homem do seu tempo e do seu país, ainda quando trate de assuntos remotos no tempo e no espaço" (ASSIS, 1992, p. 804).

A segregaçăo histórica da classe de trabalhadores pobres tentou evitar o contato direto da classe burguesa com as diferenças sociais e culturais, propulsionando as desigualdades também econômicas. Mas isso nâo impediu o protagonismo daquela gente que estava dentro das casas das famílias burguesas ou prestando serviços nas ruas e comércios da cidade. Ocorre que esse protagonismo foi demasiadamente ignorado, transformando esses homens e mulheres em sujeitos invisíveis. O ingresso da mulher no 
mercado de trabalho também é fator determinante para a compreensăo da construçăo sociocultural da cidade, já que houve uma série de rupturas no tocante à subalternizaçăo da mulher por meio do sistema patriarcal. A inserçăo da figura feminina no âmbito político, jornalístico e literário contribuiu para que a figura feminina pudesse emergir bem como todas as dificuldades do "ser mulher" em sociedade.

\title{
A PERCEPÇÃO DA CRONISTA CLARICE LISPECTOR E O DIREITO DE REIVINDICAR
}

Quando Clarice Lispector inicia os trabalhos no Jornal do Brasil (1967) com publicaçôes semanais, nota-se de imediato que a cronista chama a atençâo para a presença dos sujeitos invisíveis nas páginas da vida do carioca, a começar pela crônica "As crianças chatas", de 19 de agosto de 1967:

\section{AS CRIANÇAS CHATAS}

\begin{abstract}
Náo posso. Năo posso pensar na cena que visualizei e que é real. O filho está de noite com dor de fome e diz para a máe: estou com fome, mamáe. Ela responde com doçura: dorme. Ele diz: mas estou com fome. Ela insiste: durma. Ele insiste. Ela grita com dor: durma, seu chato! Os dois ficam em silêncio no escuro, imóveis. Será que ele está dormindo? - pensa ela toda acordada. E ele está amedrontado demais para se queixar. Na noite negra os dois estâo despertos. Até que, de dor e cansaço, ambos cochilam, no ninho da resignaçăo. E eu năo aguento a resignaçăo. Ah, como devoro com fome e prazer a revolta (LISPECTOR, 1999, p. 23).
\end{abstract}

O texto abre náo apenas a passagem de Lispector pelo Jornal do Brasil. Também náo é apenas a crônica de abertura da coletânea $A$ descoberta do mundo. Trata-se do introito clariceano que declara o perfil atento da cronista a tudo o que está acontecendo na sociedade daqueles dias. Ao mesmo tempo, "As crianças chatas" anuncia o engajamento da escritora nas questōes sociais. Para a surpresa do leitor, acostumado aos temas fúteis das colunas femininas, antes assinadas com pseudônimos, Clarice Lispector promove rupturas já na estreia como cronista ao dirigir o olhar do leitor para o problema social pungente da pobreza. Lispector agora assina o próprio nome.

Além disso, há um destaque para a percepçâo de Clarice Lispector em relaçâo às miúdas culturas em meio à realidade da época. Essa percepçăo (do latim percapere, "pegar com a mente"), aguçadíssima nas crônicas clariceanas, apontam para a compreensăo de que, por meio da identidade sociocultural, o cronista é movido pela familiaridade subjetiva do lugar epistêmico em que se encontra. Noutras palavras, a cronista "pega com a mente" os fatos externos e os une à sua própria experiência na sociedade daqueles tempos. Soma-se aí também a revolta, enquanto consequência da experiência humana que lhe é reconhecível. Por isso, o lugar epistêmico refletido na identidade do sujeito deve ser visto, no caso específico da crônica clariceana, náo apenas como um registro do circunstancial. Mais que isso, trata-se da compreensâo e, sobretudo, da reaçâo de Clarice Lispector em face do projeto cultural moderno.

Como exemplo de que o ato de "pegar com a mente" está presente no fazer literário de Clarice Lispector, vale lembrar a última entrevista concedida pela escritora em 
1977 ao programa Panorama, da TV Cultura. Na ocasiăo, o apresentador Júlio Lerner pede à escritora que explique onde foi buscar inspiraçăo para o processo de criaçăo do romance $A$ hora da estrela, ao que Lispector responde: "Eu morei em Recife, eu morei no Nordeste, eu me criei no Nordeste. E, depois, no Rio de Janeiro tem uma feira dos nordestinos no Campo de Săo Cristóvăo, e uma vez eu fui lá, e peguei o ar meio perdido do nordestino no Rio de Janeiro" (GOTLIB 1995, p. 452-60).

Além da experiência própria de quem viveu no Nordeste e, posteriormente, migrou para o Rio de Janeiro, Clarice Lispector captura a marcante presença do nordestino na cidade carioca. Diga-se de passagem, Lispector tinha o costume de ir até a Feira de Săo Cristóvấo em companhia de Olga Borelli. O ambiente era marcado pela presença de migrantes nordestinos e pobres a partir dos quais, Borelli relata ter inspirado Lispector a criar os personagens Macabéa e Olímpico (BORELLI apud MOSER, 2009, p. 542). Isso me permite pensar que, de repente, a composiçấo das crônicas tenha sido um percurso traçado pela escritora para finalmente atingir a máxima de sua qualidade "preceptora" em $A$ hora da estrela.

O olhar diferenciado daquela que chamo cronista perceptora (ALVES, 2017) requer nâo apenas a percepçáo das culturas marcadas pela diferença, mas também o reconhecimento de que os grupos desprivilegiados náo dáo conta de acompanhar a proposta moderna de sociedade. Tudo se dá de modo muito rápido, o que náo proporciona tempo para questionamentos ou reivindicaçôes. E, no caso de Lispector, a cronista vai ao encontro físico com os grupos desprivilegiados para "pegar o ar" que os perdia em meio à multidāo.

Nesse sentido, ainda no ano de 1967, Clarice Lispector publica a crônica "Entrevista alegre", na qual revela detalhes, de fato, de uma entrevista concedida por ela a uma jovem jornalista da Editora Civilizaçâo Brasileira. A jovem, chamada Cristina, traz questôes provocativas a respeito de várias questôes políticas e, sobretudo, sociais a ponto de desconcertar a cronista. Assim, Lispector relata ter manifestado seu ponto de vista, bem como seus incômodos em face da realidade brasileira daquela época:

\footnotetext{
Cristina perguntou se eu era de esquerda. Respondi que desejaria para o Brasil um regime socialista. Năo copiado da Inglaterra, mas um adaptado a nossos moldes. Perguntou-me se eu me considerava uma escritora brasileira ou simplesmente uma escritora. Respondi que, em primeiro lugar, por mais feminina que fosse a mulher, esta năo era uma escritora, e sim um escritor. Escritor náo tem sexo, ou melhor, tem os dois, em dosagem bem diversa, é claro. Que eu me considerava apenas escritor e năo tipicamente escritor brasileiro. Argumentou: nem Guimarăes Rosa que escreve tăo brasileiro? Respondi que nem Guimarăes Rosa: este era exatamente um escritor para qualquer país (LISPECTOR, 1999, p. 59).
}

Nota-se que Lispector sinaliza para uma política que favoreça a igualdade social, além de trazer à baila a consciência de que a variabilidade de lugares epistêmicos requer um pensamento e regime político que considerem as diferenças, sobretudo socioeconômicas. Do mesmo modo, quando questionada sobre os rótulos de "escritora brasileira" ou "escritora", a cronista opta pelo substantivo masculino "escritor", generalizador ou sem gênero, por considerar que o ponto de vista de quem escreve deve contemplar a mesma variabilidade social, cultural e econômica. Assim, o escritor náo 
se fixa num único lugar de significaçăo e, por isso, conclui que Guimarăes Rosa seria o "escritor para qualquer país".

Na sequência da mesma crônica, há também momentos em que Lispector deixa transparecer seu discurso denunciativo ao tratar de assuntos relacionados à subalternizaçăo de povos e culturas populares enquanto consequência da falta de comida:

[Cristina] Perguntou-me o que eu achava da literatura engajada. Achei válida. Quis saber se eu me engajaria. Na verdade sinto-me engajada. Tudo o que escrevo está ligado, pelo menos dentro de mim, à realidade em que vivemos. É possível que este meu lado ainda se fortifique mais algum dia. Ou náo? Náo sei de nada. Nem sei se escreverei mais. É mais possível que năo. Perguntou-me o que eu achava da cultura popular. Eu disse que ainda náo existe propriamente. Quis saber se eu a considerava importante. Eu disse que sim, mas que havia algo muito mais importante ainda: oferecer oportunidade de ter comida a quem tem fome. A menos que a cultura popular leve o povo a tomar consciência de que a fome dá o direito de reivindicar comida. Vide nova encíclica que fala no recurso extremo à rebeliăo em caso de tirania. Até breve, Cristina, até o nosso jantar. Você parece que também gostou de mim. O que é bom. Mas năo sei por que, depois que li a entrevista, saí tăo vulgar. Năo me parece que eu seja vulgar. E nem tenho olhos azuis (LISPECTOR, 1999, p. 60-1).

O trecho possibilita uma alusăo à reflexâo feita por Gilles Deleuze e Félix Guattari (2015) em torno do texto "Artista da fome", de Frantz Kafka. No ensaio, intitulado "O que é uma literatura menor?", os autores apreendem o termo "jejum", como sendo um dos mais recorrentes no texto de Kafka, bem como outros relacionados à fome e à mastigaçăo, e explicam:

Jejuar étambém um tema constante no que Kafka escreve, éuma longa história de jejum. $\mathrm{O}$ artista da fome, vigiado por açougueiros, termina sua carreira ao lado dos felinos que comem sua carne crua, colocando os visitantes diante de uma alternativa irritante. Os căes tentam ocupar a boca do 'câo das Investigaçóes', enchendo-a de comida, para que ele cesse de colocar suas questôes (DELEUZE; GUATTARI, 2015, p. 41).

Assim, os autores percebem no escritor tcheco uma obsessâo com relaçâo ao alimento, além da grande recorrência a expressóes relacionadas à fome e à mastigaçáo. Assim, Deleuze e Guattari compreendem que a fome apontada na narrativa de Kafka está associada a outro tipo de ausência que năo é a da comida: "falar, e sobretudo escrever, é jejuar" (DELEUZE; GUATTARI, 2015, p. 41). Isto é, a fome está relacionada à opressăo cultural que tenta calar escritores e intelectuais, como fez a censura nos tempos da ditadura. Por isso, Clarice Lispector mostra-se engajada no que se refere à realidade social, especialmente o problema da fome, enquanto cronista que "jejua", isto é, nâo se cala, mas insiste no tema.

A respeito da cultura popular, a cronista também conclui que o povo de uma naçáo que é privado do que é básico à própria sobrevivência, consequentemente năo teria punho para reivindicar direitos, tampouco subsídio no que se refere às manifestaçóes culturais. Vale retomar as palavras de Daniel Reis (2014, p. 75), no primeiro tópico deste artigo, ao afirmar que a hegemonia de fato ocorre "quando os vencedores conseguem fazer com que os vencidos usem o seu vocabulário", que por sinal encontra-se 
bem distante da franqueza. Por isso, na literatura, as figuras de estilo e linguagem favorecem a construção de ideias sem se render ao discurso hegemônico.

Deste modo, é possível afirmar que Clarice Lispector assume seu engajamento com a realidade social mantendo-se como sujeito que "jejua", isto é, opta por manifestar-se ao invés de ser indiferente em face dos problemas sociais. Lispector aponta ainda para a dificuldade de se reconhecer a cultura propriamente popular, tendo em vista que o povo brasileiro, em meio à fome e à miséria, năo teria "forças" suficientes para reivindicar direitos no que se refere às manifestaçôes culturais. Além disso, imperava o discurso hegemônico que acabava por abafar as manifestaçôes populares, supervalorizando as culturas advindas dos projetos globais.

Portanto, o tema da fome nas crônicas clariceanas năo diz respeito apenas à fome de comida, mas, sobretudo, à fome de saberes e de instruçăo suficientes para orientar a populaçấo no sentido de saber reivindicar. E, se por um lado "os câes" da ditadura tentavam calar o "cáo das Investigaçóes", por outro, havia também um projeto cultural moderno que menosprezava a verdadeira cultura popular. Por isso, Clarice Lispector promove uma conscientizaçăo que permite aos sujeitos invisíveis da sociedade a capacidade de perceber e de serem percebidos. Assim, há nas crônicas de Lispector o que Hugo Achugar (2009) chama de "olhar diferenciado", dada a apurada percepçáo da cronista que, por sua vez, promove a compreensâo de que a fome dá direito a reivindicar.

Agora, o mais interessante é que, nas últimas linhas da crônica "Entrevista alegre", Lispector faz alusâo a uma "nova encíclica" que defende a rebeliâo em casos extremos de indiferença tirana por parte do governo. Ao leitor desatento esta expressâo passaria despercebida já que a escritora náo esclarece a origem desta ideia tampouco menciona o autor do raciocínio. Mas Clarice Lispector está se referindo à Encíclica Populorum Progressio², Carta Apostólica enviada pelo Papa Paulo VI a todo o clero da Igreja Católica do mundo em 26 de março de 1967 (mesmo ano de publicaçâo da crônica em análise). A partir disso, de antemăo, nota-se que a cronista sustenta seu discurso utilizando argumentos plausíveis e, ao mesmo tempo, discretos, certamente pautados nas leituras de quem busca respostas e possíveis soluçōes para algo que tanto lhe incomoda: a fome, a miséria e a indiferença por parte do governo.

Na Encíclica, o Papa Paulo VI fala sobre os efeitos, sobretudo negativos, do colonialismo nos países africanos e latino-americanos, além de destacar o crescente desequilíbrio econômico enquanto consequência de governos ditatoriais e das guerrilhas. O entăo pontífice acabou por surpreender o mundo ao escrever o seguinte parágrafo (mencionado por Lispector na crônica supracitada) na primeira parte da carta ao tratar da "revoluçáo":

Năo obstante, sabe-se que a inquisiçăo revolucionária - salvo casos de tirania evidente e prolongada que ofendesse gravemente os direitos fundamentais da pessoa humana e prejudicasse o bem comum do país - gera novas injustiças,

2 Populorum Progressio (do latim, “O progresso dos povos”) é o nome atribuído pelo papa, e hoje santo, São Paulo VI à Encíclica datada de 26 de março de 1967. Paulo VI foi papa da Igreja Católica entre os anos de 1963 e 1978, período em que Clarice Lispector produziu a maior parte de suas crônicas. A Populorum progressio é mencionada por Lispector em algumas crônicas e, esta carta, assim como a maior parte dos textos do pontífice, destaca a necessidade de que os países do Primeiro Mundo tivessem a atitude de ajudar a resolver questões referentes à pobreza e à fome na África e em países da América Latina naquele período, sobretudo por meio de um espírito reivindicador (Cf. PAULO VI, 1990, p. 5-8). 
introduz novos desequilíbrios, provoca novas ruínas. Nunca se pode combater um mal à custa de uma desgraça maior (PAULO VI, 1990, p. 27 - grifos meus.).

Das várias definiçóes que o dicionário apresenta para o termo "revolta", destaco "manifestar-se contra" (FERREIRA, 2010, p. 642-3), o que me permite dizer que năo foi por acaso que Clarice Lispector mencionou a passagem do documento papal. A cronista busca respaldo no texto do Papa e o assimila à sua própria angústia em face dos problemas sociais para manifestar-se contrária àquela realidade e, de fato, encontra respaldo. Ainda na primeira parte da Encíclica, o líder católico assevera:

A violenta inquietaçăo que se apoderou das classes pobres, nos países em via de industrializaçáo, atinge agora aqueles cuja economia é quase exclusivamente agrária: também os camponeses tomam consciência da sua imerecida miséria. Junta-se a isto o escândalo de desproporçôes revoltantes, năo só na posse dos bens mas ainda no exercício do poder. Enquanto, em certas regióes, uma oligarquia goza de civilizaçăo requintada, o resto da populaçăo, pobre e dispersa, é privada de quase toda a possibilidade de iniciativa pessoal e de responsabilidade, e muitas vezes colocada até em condiçóes de vida e de trabalho indignas da pessoa humana (PAULO VI, 1990, p. 13).

Na "Entrevista alegre" há o singular trabalho de reflexăo do cronista que quer perceber o mundo sem, no entanto, acreditar que o que se diz deva "dirigir" a consciência do leitor. Isso porque, noutra entrevista, desta vez em 1977, à TV Cultura, quando questionada sobre o grau de interferência de seus textos na sociedade a ponto de alterar a ordem das coisas, Clarice Lispector responde clara e objetivamente: "Năo altera em nada.".

\section{"CARTA AO MINISTRO DA EDUCAÇÃO": A CRÔNICA-PASSEATA}

Na construçăo de suas crônicas reunidas em $A$ descoberta do mundo, Clarice Lispector aborda nâo apenas assuntos relacionados às desigualdades sociais, mas também a outros temas de interesse da populaçăo carioca, sobretudo no que tange a situaçăo política da época. Na crônica "Carta ao Ministro da Educaçăo", de fevereiro de 1968, a cronista se dirige ao entâo responsável pelo Ministério da Educaçâo, Tarso Dutra, que, embora tenha levantado uma luta para a reduçâo nos índices de analfabetismo no país, enfrentou dificuldades em sua gestăo e se envolveu em atritos com movimentos estudantis que eram contrários à reforma da educaçâo:

Em primeiro lugar queríamos saber se as verbas destinadas para a educaçăo săo distribuídas pelo senhor. Se năo, esta carta deveria se dirigir ao Presidente da República. A este năo me dirijo por uma espécie de pudor, enquanto sinto-me com mais direito de falar com o Ministro da Educaçăo por já ter sido estudante. O senhor há de estranhar que uma simples escritora escreva sobre um assunto táo complexo como o de verbas para a educaçăo - o que no caso significa abrir vagas para os excedentes. Mas o problema é tăo grave e por vezes patético que mesmo a mim, nâo tendo ainda filhos em idade universitária, me toca. $\mathrm{O}$ $\mathrm{MEC}$, visando evitar o problema do grande número de candidatos para poucas vagas, resolveu fazer constar nos editais de vestibular que os concursos seriam classificatórios, considerando aprovados apenas os primeiros colocados dentro 
do número de vagas existentes. Esta medida impede qualquer açăo judicial por parte dos que nâo sấo aproveitados, năo impedindo no entanto que os alunos tenham o impulso de ir às ruas reivindicar as vagas que lhes săo negadas. Senhor ministro ou senhor presidente: "excedentes" num país que ainda está em construçăo!? E que precisa com urgência de homens e mulheres que o construam? Só deixar entrar nas Faculdades os que tirarem melhores notas é fugir completamente ao problema. $O$ senhor já foi estudante e sabe que nem sempre os alunos que tiraram as melhores notas terminam sendo os melhores profissionais, os mais capacitados para resolverem na vida real os grandes problemas que existem. E nem sempre quem tira as melhores notas e ocupa uma vaga tem pleno direito a ela. Eu mesma fui universitária e no vestibular classificaram-me entre os primeiros candidatos. No entanto, por motivos que aqui năo importam, nem sequer segui a profissấo. Na verdade eu năo tinha direito à vaga. Năo estou de modo algum entrando em seara alheia. Esta seara é de todos nós. E estou falando em nome de tantos que, simbolicamente, é como se o senhor chegasse à janela de seu gabinete de trabalho e visse embaixo uma multidăo de rapazes e moças esperando seu veredicto. Ser estudante é algo muito sério. É quando os ideais se formam, é quando mais se pensa num meio de ajudar o Brasil. Senhor ministro ou Presidente da República, impedir que jovens entrem em universidades é um crime. Perdoe a violência da palavra. Mas é a palavra certa. Se a verba para universidades é curta, obrigando a diminuir o número de vagas, por que năo submetem os estudantes, alguns meses antes do vestibular, a exames psicotécnicos, a testes vocacionais? Isso nâo só serviria de eliminatória para as faculdades, como ajudaria aos estudantes que estivessem em caminho errado de vocaçăo. Esta ideia partiu de uma estudante (LISPECTOR, 1999, p. 76-7).

Conforme se nota nesta primeira parte da crônica, Clarice Lispector acompanha a situaçăo e apoia os estudantes. Um mês após a criaçăo da Aerp, Lispector demonstra indignaçăo em face da decisăo por parte do governo em limitar as vagas nas universidades durante os processos seletivos. Vale lembrar que o ano de 1968 foi marcado por protestos, como a Passeata dos Cem Mil, evento que contou com a presença de Clarice Lispector, e por atentados, além da prisáo e morte de alguns estudantes. Em 28 de março de 1968, um mês após a publicaçăo da crônica "Carta ao Ministro da Educaçăo", o estudante Edson Luis de Lima foi morto durante conflito com a Polícia Militar no restaurante Calabouço no Rio de Janeiro (FICO, 2016, p. 147).

Até este ponto do texto (supracitado) fica claro que Clarice Lispector intenta escrever menos uma crônica e mais uma carta de reivindicaçăo e protesto, como se fosse uma nota de repúdio. Como quem se manifesta em nome de muitos (e é muito provável que esta tenha sido a intençấo de Clarice Lispector), a cronista năo fala em primeira pessoa do singular, mas na primeira do plural. Além disso, é possível perceber que Lispector relaciona a falta de conhecimento e de cultura às dificuldades em fazer progredir a naçăo. Afirmar que há mais alunos do que vagas ("excedentes"), segundo a cronista, é uma manobra para nâo resolver o problema, de fato, como se deve. Uma sociedade ignorante, com homens e mulheres sem formaçăo, dificilmente terá o discernimento no tocante a outros saberes e culturas. Ao dizer que a "seara é de todos nós", mais uma vez a cronista se coloca na condiçâo de quem reivindica direitos coletivos, fazendo de seu texto uma manifestaçâo popular e estudantil conforme ela própria metaforiza: 
Se o senhor soubesse do sacrifício que na maioria das vezes a família inteira faz para que um rapaz realize o seu sonho, o de estudar. Se soubesse da profunda e muitas vezes irreparável desilusăo quando entra a palavra "excedente". Falei com uma jovem que foi excedente, perguntei-lhe como se sentira. Respondeu que de repente se sentira desorientada e vazia, enquanto ao seu lado rapazes e moças, ao se saberem excedentes, ali mesmo começaram a chorar. E nem poderiam sair à rua para uma passeata de protesto porque sabem que a polícia poderia espancá-los. 0 senhor sabe o preço dos livros para pré-vestibulares? Sáo caríssimos, comprados à custa de grandes dificuldades, pagos em prestaçóes. Para no fim terem sido inúteis? Que estas páginas simbolizem uma passeata de protesto de rapazes e moças (LISPECTOR, 1999, p. 77).

A atitude de năo se calar e questionar indica também a resistência e o constante estado de alerta da cronista. Isso significa que Clarice Lispector nâo só se preocupava com esse tipo de situaçâo, mas buscava "ouvir" o grito dos estudantes que sonhavam com uma boa educaçấo por meio da formação acadêmica. A cronista, a quem atribuo a característica de preceptora, năo se limita a indignar-se, mas busca ouvir o discurso do outro na condiçăo de inferiorizado (estudante desclassificado e oprimido pela ditadura) a fim de estreitar relaçôes e estabelecer vínculos socioculturais.

Agora, o trecho em que a parresía ${ }^{3}$ literária, isto é, a ousadia em falar francamente todas as coisas no texto literário (ALVES, 2017, p. 56), atinge o ponto máximo nesta crônica encontra-se nas linhas finais do texto. A cronista aproxima o leitor da situaçáo do estudante desclassificado e impossibilitado de se manifestar, por causa das açóes policiais que agiam violentamente contra manifestantes naquela época: Que estas páginas simbolizem uma passeata de protesto de rapazes e moças. Na conclusăo da crônica-protesto, Clarice Lispector é categórica ao manifestar-se contrária às propostas do governo para a educaçăo. A ousadia da cronista em face do regime militar, posicionando-se a favor do movimento estudantil, é mais um indício de que a parresía literária caracteriza as crônicas clariceanas. Munida disso, Lispector denuncia ainda os altos preços dos livros e o quanto é difícil para uma família manter filhos nos cursinhos pré-vestibulares com os salários que recebiam. Assim, é possível afirmar que a parresía corrobora o perfil do cronista perceptor que, por sua vez, precisa desabrochar em coragem para pegar com a mente a realidade do outro oprimido.

Além disso, Silviano Santiago no artigo "A política em Clarice Lispector", chama de "ativismo coletivo" náo apenas a participaçáo de Lispector em passeatas (Imagem 1), mas também os textos cheios de certa ousadia-tímida, e que esse ativismo "robustece a arte pelo avesso, liberando-a do compromisso que a literatura brasileira tradicional mantém com o acontecimento sócio histórico" (SANTIAGO, 2014). O vínculo pelo coletivo reforça a característica de perceptora em Lispector que, por sua vez, nâo se associa a grupos partidários específicos a fim de náo se comprometer com os fatos, mas com a própria arte.

3 Segundo Michel Foucault, em 0 governo de si e dos outros (2010, p. 42), o termo parresía é de origem grega e significa "fala franca" ou "liberdade de palavra". 


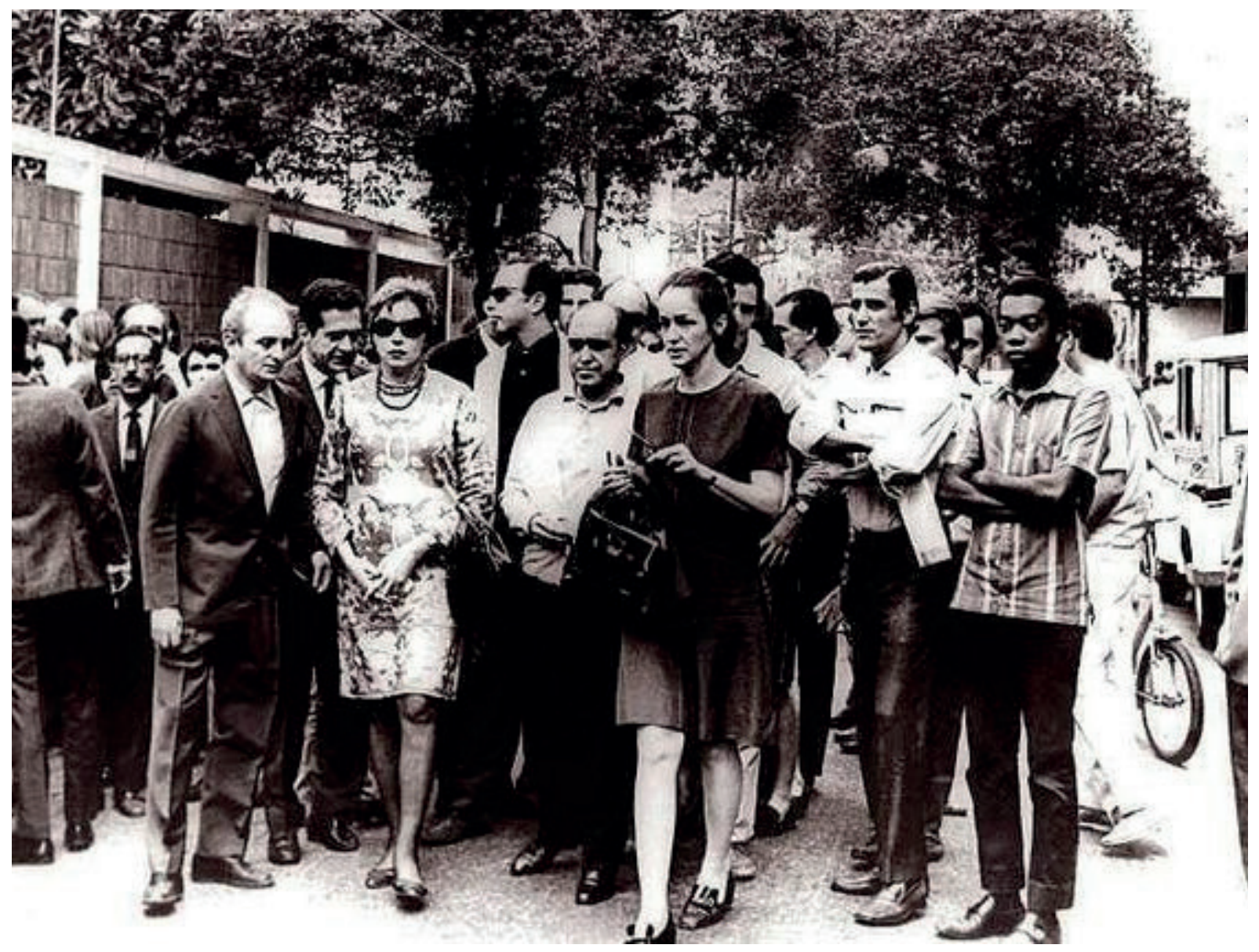

Imagem 1: Clarice Lispector na Passeata dos Cem Mil, em 1968. À direita dela aparece Carlos Scliar e, à esquerda, Oscar Niemeyer, Glauce Rocha, Ziraldo e Milton Nascimento.

Fonte: Clarice fotobiografia (GOTLIB, 2008, p. 374).

Nos anos subsequentes, Clarice Lispector publicaria outras crônicas mais sucintas nas quais usa constantemente a palavra "liberdade". De modo um tanto subliminar, a cronista traz nos textos o maior anseio de quem precisa se manifestar constantemente para devorar com fome e prazer a revolta. No trecho a seguir, da crônica "O ato gratuito", de 1972, Lispector escreve:

Era profundo o cansaço da luta. E percebi que estava sedenta. Uma sede de liberdade me acordaria. Eu estava simplesmente exausta de morar num apartamento. Estava exausta de tirar ideias de mim mesma. Estava exausta do barulho da máquina de escrever. Entăo a sede estranha e profunda me apareceu. Eu precisava - precisava com urgência - de um ato de liberdade: do ato que é por si só. Um ato que manifestasse fora de mim o que eu secretamente era. E necessitava de um ato pelo qual eu náo precisava pagar. Náo digo pagar com dinheiro mas sim, de um modo mais amplo, pagar o alto preço que custa viver (LISPECTOR, 1999, p. 410).

De fato, era preciso lutar contra um regime opressor que limitava por meio da censura ou da açâo violenta da polícia qualquer manifestaçâo contrária ao governo. Se a 
fome era de comida e de saberes, a sede era de liberdade. E, voltando ao ano de 1969, na única linha que compôe a crônica "Mas já que se há de escrever", Clarice Lispector (1999, p. 200) assevera: "Mas já que se há de escrever, que ao menos nâo esmaguem as palavras nas entrelinhas". O ofício de escrever crônicas enquanto arte de falar ao público por meio do registro do cotidiano e, ao mesmo tempo, promover reflexóes, naqueles tempos, era um ofício desafiador. Mas, embora a crônica tenha como uma das principais características a objetividade e a concisâo, nas entrelinhas o cronista encontrava alternativas para driblar a censura.

Entretanto, nem sempre os artistas e intelectuais buscaram se manifestar apenas por meio das entrelinhas. Naquela época, músicos como Caetano Veloso e Chico Buarque compuseram as chamadas "cançôes de protesto". Do mesmo modo, a estilista Zuleika de Souza Netto, a Zuzu Angel, ficou nacionalmente conhecida por ter enfrentado a ditadura antes e após o desaparecimento do filho militante Stuart Angel Jones em 1971: “O ano de 1967 foi emblemático para a carreira de Zuzu, pois, em plena ditadura militar, ela realizou um desfile com o nome Fashion and Freedom (Moda e Liberdade), o que representava claramente uma crítica ao regime" (SCHEMES et al., 2012, p. 290). Zuzu Angel morreu em um acidente suspeito no ano de 1976, após uma incansável luta por informaçōes a respeito do filho considerado "desaparecido político". Durante os "desfiles de protesto", um dos símbolos que passou a ser estampado nas roupas produzidas da estilista naquela época foi o passarinho engaiolado, como uma forma de manifestaçăo contrária ao governo vigente.

A representaçâo do passarinho aprisionado surge também na crônica de Clarice Lispector um ano após a morte de Stuart Angel Jones, no texto intitulado “Taquicardia a dois", publicado em abril de 1972 . O pássaro, grande símbolo da liberdade, aparece no texto em momento cotidiano, porém inusitado, conforme o relato da cronista:

\begin{abstract}
Estava minha amiga falando comigo ao telefone. Eis entăo quando entra-lhe pela sala adentro um passarinho. Minha amiga reconheceu: era um sabiá. A empregada se assustou, minha amiga ficou surpresa. Era preciso que ele achasse o caminho da janela para ir embora e escapar da prisăo da sala. Depois de esvoaçar muito, pousou num quadro acima da cabeça de minha amiga, que continuou o telefonema, porém mais atenta ao sabiá do que às palavras. Foi quando sentiu uma coisa pelas costas nuas - era verăo, o vestido náo tinha costas: o sabiá tinha-se aninhado nela e parecia estar muito bem. É preciso dizer que minha amiga tem uma voz muito suave. Ela sabia que qualquer movimento súbito seu, e o sabiá se assustaria quase mortalmente. Desligou o telefone. Também preciso dizer que minha amiga tem máo e jeito leves, é capaz de segurar a corola de uma flor sem fazê-la murchar. Foi com seu jeito leve que pegou no sabiá, que se deixou pegar. E lá ficou o sabiá na măo. $O$ coraçấozinho do sabiá batia em louca taquicardia. E o pior é que minha amiga estava toda taquicárdica. Ali, pois, ficaram os dois tremendo por dentro: a amiga sentindo o próprio coraçáo palpitar depressa e na máo sentindo o bater apressadinho e desordenado do sabiá. Entăo ela se levantou devagar para năo assustar o que estava vivo na sua măo. Chegou junto da janela. O sabiá compreendeu. Minha amiga espalmou a mấo, onde o sabiá permaneceu por uns instantes. E de súbito deu uma voada lindíssima de tanta liberdade (LISPECTOR, 1999, p. 412).
\end{abstract}

A invejável habilidade do pássaro em alçar o voo da liberdade sucede após o animal experimentar o ambiente fechado da sala de uma casa que tinha telefone e 
empregada. Apesar de tratar-se de um fato cotidiano, aparentemente banal, Clarice Lispector aproveita o ensejo para promover uma reflexăo a respeito da liberdade. No Brasil daqueles dias, estar na segurança de uma casa nem sempre era sinônimo de comodidade, mas de aprisionamento e opressăo.

A sala é o lugar onde a família se reúne para receber amigos e falar sobre tudo. $\mathrm{Ou}$, para sentar e ler o jornal. Inclusive a empregada está presente na sala, segundo a cronista. Na medida em que o leitor caminha os olhos pelo texto, a sensaçâo é de que o sabiá está nas máos de quem lê, e o bater apressadinho do coraçăo do pássaro pode ser praticamente sentido por meio dessa leitura. "O que estava vivo" na mâo do leitor naquele momento é a crônica, que entra na casa trazendo consigo o alvoroço dos fatos daqueles dias sem liberdade. $\mathrm{O}$ momento efêmero da passagem do passarinho pela casa deixa vestígios do que é a leveza do ser livre em detrimento dos temerosos dias de regime militar. Mas, ao mesmo tempo, provoca no leitor o desejo de, de repente, descer do sobrado.

\section{CONSIDERAÇÕES FINAIS}

Mas já que se há de escrever, era preciso que Clarice Lispector o fizesse enquanto sujeito de seu tempo, engajada nas causas sociais e empenhada em chamar a atençâo do leitor no sentido da percepçáo do outro subalterno e oprimido. E até mesmo a reconhecer-se como parte deste grupo de pássaros engaiolados. Nem sempre a pungência dos temas relacionados às desigualdades sociais provocaria a mesma sensaçấo de leveza que a visita de um passarinho pode provocar.

A cronista trata de assuntos relacionados ao problema da fome e também às classes sociais desfavorecidas em contato com a classe burguesa carioca. Entretanto, a fome é sem dúvida a razáo maior pela qual a cronista perceptora assume o engajamento literário. O manifesto dirigido ao Ministro da Educação estatela os olhos do leitor nos dias de hoje e, possivelmente, provocou alvoroço nos leitores do Jornal do Brasil daquele tempo. Nas palavras da própria Clarice Lispector, tudo o que se escreveu ali "năo altera em nada!", mas permite-nos apontar a parresía literária de uma cronista empenhada em manifestar-se por meio de seu "ativismo coletivo" e năo resignar-se como a mâe das "crianças chatas".

\section{REFERÊNCIAS}

ACHUGAR, Hugo. Culpas e memórias nas modernidades locais: divagaçôes a respeito de "O flâneur" de Walter Benjamin. Trad. Rômulo Monte Alto. In: SOUZA, Eneida Maria de; MARQUES, Reinaldo [Org.]. Modernidades alternativas na América Latina. Belo Horizonte: Editora UFMG, 2009. p. 14-31.

ALVES, Joyce. Ao belo cabe prender o cisco: a cronista perceptora na parresía de Clarice Lispector. 2017. 169 f. Tese de Doutorado em Letras (Literatura Comparada) Universidade Estadual de Londrina, Londrina/PR, 2017. 
ASSIS, Machado de. Obra completa. Volume 3. Afrânio Coutinho (org.). Rio de Janeiro: Nova Aguilar, 1992. (Série Brasileira)

BOSI, Alfredo. História concisa da Literatura Brasileira. 3 ed. Săo Paulo: Cultrix, 1997.

BRAGA, Rubem. O poeta e outras crônicas de literatura e vida. Gustavo Henrique Tuna (org.). Săo Paulo: Global, 2017.

CASTRO, Josué de. Geografia da fome: o dilema brasileiro - páo ou aço. 10 ed. Rio de Janeiro: Ediçōes Antares, 1969. (Clássicos das Ciências Sociais no Brasil)

DELEUZE, Gilles; GUATTARI, Félix. O que é uma literatura menor? In: _. Kafka: por uma literatura menor. Trad. Cíntia Vieira da Silva. Belo Horizonte: Autêntica Editora, 2015. p. 35-53.

FERREIRA, Aurélio Buarque de Holanda.Mini Aurélio: o dicionário da Língua Portuguesa. 8 ed. Curitiba: Positivo, 2010.

FICO, Carlos. História do Brasil contemporâneo: da morte de Vargas aos dias atuais. Săo Paulo: Contexto, 2016. (Coleçâo História na Universidade)

FOUCAULT, Michel. O governo de si e dos outros: curso no College de France (1982-1983). Trad. Eduardo Brandāo. Săo Paulo: Martins Fontes, 2010.

GOTLIB, Nádia Battella. Clarice: uma vida que se conta. Săo Paulo: Ática, 1995.

_. Clarice Fotobiografia. Sáo Paulo: Editora da Universidade de Sáo Paulo, 2008.

GUARNIERI, Gianfrancesco. Eles nâo usam black-tie. 19 ed. Săo Paulo: Civilizaçâo Brasileira, 2008.

LISPECTOR, Clarice. A descoberta do mundo. Crônicas. Rio de Janeiro: Rocco, 1999.

MOSER, Benjamin. Clarice,. Trad. José Geraldo Couto. Sâo Paulo: Cosac Naify, 2009.

PAULO VI. Populorum Progressio. Carta Encíclica de Sua Santidade o Papa Paulo VI Sobre o desenvolvimento dos povos. Trad. Poliglota Vaticana. 12 ed. Sáo Paulo: Paulinas, 1990.

REIS, Daniel Aarâo. Ditadura e democracia no Brasil: do golpe de 1964 à constituiçăo de 1988. Rio de Janeiro: Zahar, 2014.

SÁ, Jorge de. A crônica. Sáo Paulo: Ática, 1987. (Série Princípios) 
SANTIAGO, Silviano. A política em Clarice Lispector. Rio de Janeiro: Coluna Especial Blog da Editora Rocco, 31 out. 2014. Disponível em: https://www.rocco.com.br/blog/a-politica-em-clarice-lispector/ Acesso em: 20 out. 2017.

SCHEMES, Claudia; ARAÚJO, Denise Castilhos de; PUHL, Paula Regina. As manifestaçôes femininas na tela: Zuzu Angel e a moda-protesto. Caderno Imagem. In: Polêmica. Revista Eletrônica Interdisciplinar da UERJ. v. 11, n. 2, Rio de Janeiro, 2012. p. 285306. Disponível em: http://www.e-publicacoes.uerj.br/index.php/polemica/article/ view/3101/2222 Acesso em: 17 out. 2017.

VIEIRA, Cássio Leite. Oswaldo Cruz e a varíola: a revolta da vacina. Superinteressante. Ano 8, n. 11, Sáo Paulo, Editora Abril, nov. 1994. p. 66-71. 